\title{
Politik Bir Araç Olarak Terörizmin Kurumsallaşması: Huntington ve Giddens
}

\author{
DOI: 10.26466/opus.738465
}

*

\section{Mehmet Özcan*}

* Öğr. Gör.Dr. Mehmet Özcan, Ankara Hacı Bayram Veli Üniversitesi, Polatlı Sosyal Bilimler MYO. Polatl//Ankara

E-Posta: $\underline{\text { mehmet.ozcan@hbv.edu.tr }}$

ORCID: $\underline{0000-0001-7350-7855}$

\section{Özet}

Terör veya terörizm her ne kadar Fransız Devrimi ile birlikte sosyal bilim literatürüne girmiş olsa da özellikle 2001 Dünya Ticaret Merkezi saldırısı sonrası anlamının yeniden şekillendiği aşikardır. Kendi içinde belirli amaçlara ulaşmayı hedeflemekle birlikte terörizm özellikle Soğuk Savaş sonrası dönemin yeniden inşasında kilit bir rol oynamıştır. Makalede bir kavram olarak terörizmin araçsallaştırılması ve terör faaliyetleri aracıllğ̆ıla rutinleştirileren güvenlik politikalarının meşruiyeti tartışmaya açılmıştır. Bu bağlamda terörizmin günümüz dünyasında nasıl ortaya çıktı̆̆ın kavramak adına Huntington'un 'medeniyetlerin çatışması' teorisi tartışılmıştır. Politik gelişmelerin yorumlanmasında ortaya çıan düşünsel farklılıkları görmek açısından iki farklı düşünürün kavramsallaştırmaları çerçevesinde günümüzdeki temel tartışma konularından biri olan terörizm kavramı ele alınmıştır. Aynı zamanda bu durumun politik tartışmalar için her zaman bir teorik konsensusu da beraberinde getirmediği söylenebilir..Geç modern dünyada terörizmin anlaşılabilmesi adına Huntington'un teorisine Giddens'ın yaptlaşma teorisi perspektifiyle müdahale edilerek terörizmin 'kalıplaşmış hakikatleri' korumak adına 'fundamentalizmin' yeniden diriltilmesinin aracı olduğu dile getirilmiştir. Bu kapsamda geç modern toplumlarda terörün kurumsallaştı̆̆ı iddiası anlaşılmaya ve değerlendirilmeye çalışılmıştır.

Anahtar Kelimeler: Terör, Medeniyetler Çatışması, Öteki, Antony Giddens 


\title{
Institutionalization of Terrorism as a Political Instrument: Huntington and Giddens \\ *
}

\begin{abstract}
Although terrorism entered the social science literature with the French Revolution, it is obvious that meaning reshaped, especially after the 2001 World Trade Center attack. Terrorism has played a key role in rebuilding the post-Cold War era, although it aims to achieve specific goals in itself. In the article, the legitimacy of security policies, which is routine through the instrumentalization of terrorism and terrorist activities as a concept, is open to discussion. In this context, Huntington's "clash of civilizations" theory discussed to understand how terrorism emerged in today's world.. To see the intellectual differences in interpreting political developments, the concept of terrorism, which is one of the main topics of discussion today, has been handled within the framework of the conceptualization of two different thinkers. It can also be said that this situation does not always bring about a theoretical consensus of political debates. It stated that Huntington's theory interferes with Giddens' perspective on construction theory to understand terrorism in the late modern world and that it means to revive 'fundamentalism' to protect 'stereotypes'. In order to understand terrorism in the late modern world, it has been stated that Huntingteon's theory was intervened with Giddens' perspective on the theory of construction, and it was the means of resurrecting 'fundamentalism' in order to protect 'stereotypes'. In this context, the claim that terrorism was institutionalized in late modern society justified.
\end{abstract}

Keywords: Terror, Clash of Civilizations, Other, Antony Giddens 


\section{Giriş}

Kavramlar teorik düzeyde bir düşünme faaliyetinin kaçınılmaz unsurları olarak ele alınmalıdır. Kavramlar olmaksızın bir düşünme faaliyeti yürütülemez. Kavramlar olmaksızın dünyayı deneyimlerimiz aracılığıla düşünebileceğimizi iddia eden yaklaşımlar olsa da bu imkânsız olarak kalacaktır. Kavramlar aracılığıyla gerçeklik ile temas kurar ve dünyayı biliriz. Dolayısıyla kavramlar düşünürler için görme biçimleri üretir. Görme biçimleri -paradigmalar/yaklaşımlar- tamamıyla kavramsal bir düzenek olarak değerlendirilmelidir. Dünyayı görme biçimlerimizin bir kavramsal mekanizma olduğunu söylemek sadece felsefi düzeyde bir argüman olarak değil bunlarla birlikte politikaya, tarihe ve topluma ilişkin de bir değerlendirme olarak görülebilir. Kavramsal mekanizmalar, bir aygit olarak siyasal aktörler tarafından bir konum üretmek ya da bulunulan konumu tahkim etmek için istihdam edilebilirler. Bu çalışmada 'terör' kavramı günümüz dünyasında belirsiz ve etkili kavramlardan birisi olarak ele alınmış olup nasıl kurumsallaştığı tartışmaya açlmıştır.

20. yüzyılın etkili sosyal teorisyenlerinden biri olan Michael Foucault'un temel çalışmalarından biri kavramların tarihsel konumunu düşünmeye dönüktür. Kavramların "söylemin düzeni"nde bir iktidar aritmetiğinin temel bileşenleri olarak nasıl mevzilendirildiklerini toplumsal teori açısından değerlendirmeye çalışır (Foucault,2001). Bu çerçevede epistemoloji bir söylem olarak görülmektedir. Söylem iktidarın kutsal topraklarıdır. Söylem; bilgi ve iktidar arasındaki dostluğun bileşkesi olarak tarihsel ontolojidir. Kavramlar söylemin ekonomisinde mevzi alır. Kavramların tarihsel oluşumuna, macerasına ve bunun nasıl üretildiği söylemin konusudur. Bütün kavramlar zamanın akışına bağlıdır. Kavramlar da doğarlar, büyürler ve ölürler. Kavramların oluşumu ve tarihle ilişkisi güç siyasetinin hegemonya arayışının ekonomisine bağlıdır. Bu yönüyle düşünmenin görevi kavramın tarihle olan ilişkisinde kavramı hegemonyanın taleplerinden arındırıp onu kendine döndürmektir. Kavramları tarihin, politikanın ve bütünsel olarak hegemonyanın ölümcül iştahının ağzından kurtarmak düşünmenin sorumluluğudur. Her türlü iletişim bu entelektüel iradeye sahip olmalıdır. Kavramların hegomanik taleplere uygun olarak konuşlandırılması bir felakettir. Hegemonya dünyayı iktidar mantığına uygun birinin lehine diğerinin aleyhine olarak kurulması 
ya da düşünülmesidir. Görme biçimlerinin siyasal ve toplumsal hakikati sürekli iskalamasının arka planında da bu yatar. Düşünmenin ve her türlü yorumlama stratejilerinin çıkmazıdır bu durum. Günümüzün politik söylemlerinin ve stratejik mekanizmalarının en önemli işlevsel-ekonomik kavramlarından biri de "terör" kavramıdır. Terör kavramı kolaylıkla dini ya da politik bir söylemle birlikte kullanılabilir. Bu yönüyle terör kavramı hegemonya siyasetinde savaş stratejisinin temel bir aracıdır.

Bu çalışma terör kavramını doğru bir anlama kavuşturmaya dönük bir çaba olarak görülmelidir. Terör kavramı Fransız ihtilali sürecinde geleneksel tarihsel yapının yerine düzenin tesis edilmediği dönemin siyasal ortamına, bir anlamda belirsizliğe işaret eden bir kavram olarak dolaşıma girmiştir (Laguer, 2002).Terörün yıkıcllı̆̆ karşısında insanlığın birbirini anlaması "doğru iletişim" in kurulmasıyla sağlanabilir (Habermas,2001). Bugün terör kavramı konusunda bütün açıklığıyla bir konvansiyondan bahsetmek mümkün değildir. Uluslararası toplumun bu kavram konusunda bir uzlaşıma sahip olduğu söylenemez. Kavramın hukuki içeriği konusunda da bir tartışma bu çalışmanın kapsamına girmemektedir. Burada daha çok Newyork, Madrid, İstanbul ve Londra yerlerdeki olaylardan sonra oluşan söylemlere baktı̆̆1mızda bir şekilde terör kavramıyla İslam'ın ilişkilendirilmeye çalışıldığı görülür. Şüphesiz terörist eylemler meşrulaştırılamaz ve kategorik olarak lanetlenmelidir. Terörizm yok edici bir pratiktir. Nihilistik bir eylemdir. Onun için her şekilde onun karşısında durulmalıdır.

$\mathrm{Bu}$ çalışmada öncelikle terörün kurumsallaşma sürecine bağlamında Huntington'un medeniyetler çatışması tezi değerlendirilerek ancak bunun yeni gelişmeler ile birlikte bu tezin geçerli olmadığı tartışmaya açılmıştır. Akabinde Giddens'in yeniden yerleştirme ve yerinden etme kavramları çerçevesinde geç modern toplumlarda küreselleşmenin beraberinde getirdiği bir risk olarak şiddet eğilimi ve bu eğilimin yarattığı bir fundamentalizmin temel araçlarından biri olarak terörün yorumlanmasına çalışılmıştır. Uluslararası ilişkiler açısından terörün kaynağı, kimler tarafından beslendiği şeklindeki komplo içeren tezler çalışmanın kapsamı dışında tutulmuştur.

\section{Terörün Kurumsallaşması}

Sosyoloji literatüründe Durkheim'ın (2012) işlevselciliği; Atlantik ötesinde Giddens'a (2011, s.103) göre Malinowski ile birlikte yeniden hayat bulan işlevselcilik ve Parsons ile birlikte yapısal-işlevselciğin 1960'lara damga vuran 
gelişimi kurumların ya da kurumların oluşum süreçlerinin bireye dışsal olduğu ve özellikle Durkheim'a atıfla 'baskı' uygulayabilen bir organizma olarak görüldüğü söylenebilir. Parsons ile birlikte organizmacı yaklaşım yerini 'çarklar'a yani sistem kavramsallaştırmasına bırakmıştır. Ancak Weber' in eylemin 'niyetlenilmemiş sonuçları'nın olabileceği iddiası neticesinde yorumsamacı yaklaşım -güçlü yankısını fenomenolojik yöntemlerde bulur- gelişmiştir. Bu yaklaşımlarda sosyal dünyanın yani kurumların, pratik icralar ile oluştuğu ve aktörün bu oluşum sürecinin bizzat faili olduğu öne sürülmüştür. Bu tartışmaların geniş bir külliyat oluşturduğu kabul edilmekle birlikte bu çalışmada özellikle Berger ve Luckman'ın (2008) tartıştığı 'kurumsallaşma' olgusu referans alınmıştır. Onlara göre kurumsallaşma (2008, s.80) "mutatlaştırmaya ( habitualization) tâbidir. S1k sık tekrarlanan her eylem, sonradan bir efor tasarrufuyla yeniden-üretilebilen ve icracıları tarafından ipso facto bir model olarak kavranan bir kalıba dökülmeye başlar. Mutatlaştırma ayrıca, söz konusu eylemin gelecekte aynı tarzda ve aynı tasarruflu eforla tekrar edilebileceğini de imâ eder". Dolayısıyla tekrar ve tekrar yapılan eylemlerin kalıplaşması kurumsallaşmanın temel dinamiğini oluşturmaktadır.

Berger ve Luckman'ın kurumsallaşma sürecini ele alırken üç kavram öne sürmektedirler. Dişsallaşma, nesnelleşme ve içselleştirme. Bu süreçlerin neticesinde kurumların geliştiğini ifade ederler. Bu süreçleri ise şöyle açılamaktadırlar:

“İnsanî faaliyetin dışsallaşmış ürünlerinin nesnellik karakteri kazandığı süreç, nesnelleşmedir. Kurumsal dünya, nesnelleşmiş insan faaliyetidir ve her bir kurum için bu geçerlidir. Başka bir deyişle, nesnellik, İnsanî tecrübedeki sosyal dünyaya işaret ediyor olsa da, onu üreten insan faaliyetinden bağımsız ontolojik bir statü asla kazanmaz. ... Dışsallaşma ve nesnelleşme, süre giden bir diyalektik sürecin uğraklarıdır. Bu sürecin üçüncü uğrağı, yani (nesnelleşmiş sosyal dünyanın sosyalizasyon esnasında bilince geri dönmesi aracılığıyla ortaya çıkan) içselleştirmedir" (Berger ve Luckmann, 2008, s.1-92).

İnsan eylemi olarak korkutucu faaliyetler, belirli tekrarlar sonucu rutinleşerek bir alışkanlık da üretmektedir. Her ne kadar korku ve dehşete alışmak imkansız da olsa 'yeni-normal' olarak bu faaliyetler ile birlikte yaşamanın imkanını bireylere düşündürtürler. Terör eylemleri, bu anlamda insan eylemliliğinin bir dışsallaşma -terör eyleminin gerekçelendirilmiş şekli- ve sonuçları itibariyle de nesnelleşmesi -doğurduğu sonuçlar- sürecini ifade etmektedir. 
İçselleştirilmesi ise iki farklı şekilde gerçekleştiği bu çalışmada ifade edilmiştir: Bunlardan ilki, terörist olarak yetiştirilme ve dolayısıyla terörist eylemliliğini süreklileştirici bir sosyalizasyon süreci olup terörizme kaynak sağlama anlamında yıkıcı etkileri açısından ifade edilebilir. İkinci olarak; terörist eylemlilik sürecinin olumsuzlanarak içselleştirilmesi şeklinde devam eden bir sosyalizasyon süreci söz konusu olup bu türü de siyasal arenada 'güvenlik politikalarını' haklılaştırmaya dönük bir işlev görmektedir.

Terörün kurumsallaştırılma süreci her toplumda farklı derecelerde olduğu söylenebilir. Ancak tüm bunlarla birlikte geç modernlikte terörün bir kurumsallık eğilimi içinde olduğu hatta bizzat kurumsallaştığı da açıkça söylenebilir. Çünkü artık bir terör tarihinden bahsedebilmekteyiz. Nitekim kurumsallaşma sürecinin tamamlanması terör eylemlerinin tarihselliğinin oluşumu ile mümkündür. Başka bir deyişle terörün tarihsel bir entite olarak faaliyet sürdüğü ve günümüz dünyasında terör ile birlikte yaşamayı öğrenmek zorunda kalındığı bir gerçek olarak karşımızda bulunmaktadır. Kurum "insan toplumlarının organize ettiği ve insanın ihtiyaçlarına çeşitli derecelerde cevap verecek, onları idare edip yönetecek bir sosyal yapı ve mekanizmadır" (Adak, 2011, s.29). İnsanlar ihtiyaçlarını giderme konusunda farklı farklı metodlara başvurabilmektedirler. Nitekim bu metodlardan biri olarak terörizm ele alınabilir. Örneğin terörün nedenlerinin tartışıldığı birçok metne bakıld1ğında şu nedenler ile karşılaşılmaktadır: Sefalet, hüsran, dert, keder ve umutsuzluk, iktisadi ve sosyal eşitsizlik, kaynak kıtlığı, hukuksal sorunlar, siyasal faktörler, sömürgeye direniş, ideoloji, psikolojik sorunlar, siyasal baskı ve şiddet (TBB, 2006). Genel olarak terörizmin 'eski düzen'i yıkma amacında olduğu da söylenebilir. Elbette bu amaç için bu tarz bir çaba hiçbir zaman meşru kabul edilemez.

İfade edildiği gibi terörizmin kurumsallaşması süreci ilginç bir şekilde 2001 ve sonrasına tekabül etmektedir. Bu bağlamda DTM olayı referans alındığında terörün kurumsallığının farklı sonuçlarının olabileceği de düşünülmelidir. Başka bir deyişle 2001 ile kurumsallaşmasını tamamlamış bir örgütlenme biçimi olarak terör, insanların gündelik yaşamlarının büyük bir kısmı üzerinde biçimlendirici bir etkisi söz konusudur. Bu gelişmelerin aynı zamanda şiddet, ulus devlet ve küreselleşme ile de yakından ilişkili olduğu ilerleyen kısımlarda detaylı bir şekilde ifade edilmiştir. 


\section{Şiddet ve Medeniyetler Çatışması: Huntington'un Yorumu}

Weber devlet tanımını şiddet üzerinden yapar. Devlet onun tabiriyle 'fiziksel güç ve şiddet tekelini elinde tutar (Weber, 2004). Bu tekel devletin en belirgin özelliklerinden biri olarak halen geçerliliğini sürdürmektedir. Üstelik bu nitelik tarihseldir. Örneğin Foucault'un Hapishanenin Doğuşu (1992) kitabı bu şiddet tekelinin bir örneği olarak görülebilir. Ancak modernite ile birlikte bu şiddet uygulama yaklaşımları değişmiştir. "Cezalandırma iktidarının yeni bir ekonomisini ve yeni bir teknolojisini oluşturmak" (Foucault,1992, s.110). Değişen bu iktidar teknolojisi artık bedenlerin disipline edilmesi üzerinden işlemektedir. Dolayısıyla modernitenin şiddeti reddetmesinden öte onu dönüştürdüğü ifade edilebilir. Nitekim Weber modern devletin doğuşuna tam da bu şiddet tekelini yerleştirir. Dolayısıyla Giddens'a göre moderniteden kopmadığımıza göre hala devlet şiddet tekeli üzerinden varlığını ete kemiğe büründürür. Bu bağlamda dehşet uyandırmak gibi bir mantıkla hareket eden terörist faaliyet Foucault'un ortaçağ uygulamaları örneğini çağrıştırır. "Azap çektirmenin ortadan kalkması demek, seyirlik unsurun silinmesidir; ama aynı zamanda bedenin tutuklanmasıdır (Foucault,1992, s.12). Dolayısıyla dehşet uyandırmak isteyen terör, hiçbir şekilde meşruiyeti olmayan bu tarz bir eylemlilik şeklini seçmektedir. Dolayısıyla terörist faaliyetin elinde uygulayabileceği şiddet türü modern cezalandırma sistemleri tarafından anlamsızlaştırılmıştır. Bu nedenle de terörist eylem hiçbir zaman devlet yanlısı olamayacak ve siyasal başlangıçlar da daima teröristçe olacaktır. Bu terörizmin kısır döngüsüdür.

Sosyal bilimcilerin bir kısmının dönemleştirmeler aracıllğıyla düşünmeye eğilimli oldukları bilinir. Dönem kendi içinde belirli bir paradigma içinde ele alınır. Genellikle bu bir kolaylaştırma modeli olarak değerlendirilebilir. Burada yirminci yüzyılın ikinci yarısı (doksanlara kadar) bu çerçevede siyasi tarih ve uluslararası ilişkiler açısından soğuk savaş dönemi olarak tanımlandı. Bu dönemin kendine özgü siyasal paradigması içerisinde büyük ölçüde bir dünya yorumu yapıldı. Bu döneminin bitiminde ortaya çıkan siyasal belirsizlik bütün toplumsal yapıları da belirsizleştirdi. Bugün bir düzen arayışının varlığı kendisini çok açıkça hissettirmektedir. Bugün uluslararası makro siyasi yapılara ilişkin sorular da bu duruma işaret eder. NATO ve BM hakkındaki tartışmalar açıkça dile getirilmektedir. Bu kurumların dayandığı meşruiyet temeli kurumların temel aktörleri tarafından da paylaşılmaktadır. Soğuk 
savaşın bitiminde belirsizlik uluslararası sistemi etkilemeye başladı. Belirsizliği bertaraf etmeye dönük olarak devreye giren en önemli kavram terör kavramı ve bunun önüne getirilen İslami sıfatı olmuştur. Terör kavramı soğuk savaş sonrası dönemde dağılan hegemonyanın, kaybolduğu düşünülen istikrarı geri getirmek için üretilen son derece belirsiz operasyonel bir kavram olarak konumlandırılmıştır. Artık istikrar ve terör birlikte telaffuz edilmektedir. Ne gelir dağılımı ne küresel eşitsizliğe dayalı gelişme mantığı bu tür tartısmalarda başvurulan unsurlar değildir. Ya da süren savaşlar ve yıkımların bu tartışmalarda bir karşılıkları yoktur. Soğuk savaşın bitiminde ya da tarihin sonunda aslında yeni bir tarih ve gelecek perspektifleri de dolaşıma girdi. Yeni dönemin ve gelmekte olan düzenin temel değerlendirmesi Samuel Hungtington'un (2001) 'Medeniyetler Çatışması ve Dünya Düzeninin Yeniden Kurulması" isimli çalışmasıdır. Çalışma uluslararası ilişkilerde çatışmanın mantığının farklılaştığını öne çıkarmıştır. Bu farklılaşma artık sorunun ekonomik ya da politik olmadığını vurgulayarak çatışmanın medeniyetler arasında gerçekleşeceğini ileri sürmüştür. Medeniyet kavramı, yaşam biçimleri kültürel kimler ve bu bağlamda artık çatışmanın temel belirleyici unsurları olarak görülmüştür. Bu değerlendirme çerçevesinde terör ve İslam kavramlarının birlikte kullanılması daha da kullanışlı bir teorik zemine kavuşuyordu. Bu çalışma aynı zamanda geçmişteki metodolojilerle de buluştuğunda direk bir karşılık buluyordu. Oryantalizm tartışmaları bu bağlamda ele alınabilir. Medeniyet kavramı oryantalist okumalarda temel değerlendirmelerle ele alınmıştı. İŞiD ya da DEAŞ günümüzün siyasal gündeminde bu yönüyle dikkatlice ele alınması gerekmektedir. İmgesel ve politik düzeyde bu az önce dile getirilen oluşum bu konumlandırmaya son derece temel bir katkı olarak görülebilir. Bu durum İslam'ın negatif bir yaklaşımla ele alınarak tarih içerisinde olumsuz bir imge olarak konumlandırılmasına yol açmıştı. (Said,1999).

İslami terör kavramı bu perspektif üzerinden ele alındığında bir karşılık bulacaktır. Medeniyetler çatışması kültürel merkezli politik oluşum ve çatışmalara işaret eden ve bunu teorileştiren bir çalışmadır. İslam bir din ve kültür olarak bu oluşumlara kaynaklık eden bir kültür olarak okunur. Bu perspektif kültürel analizler ve politik teorinin buluşmasından ortaya çkan bir kavrayış olarak görülebilir. Yalnız kültürü ötekileştirerek düşünmek sadece tarihsel antagonizmaları yeniden üretecektir. Bu teorik girişim geçmişin birbirine sa- 
ğır yapılarını tekrar cepheye çağırıyor. Ötekiyi ötekileştiren bütün kuramlaştırmalar ve kavramlar bir epistemoloji disiplini içinde şiddetin üretilmesi olarak görülmelidir.

Devlet karşıtı anlamında terörizmin soğuk savaş sonrası rolünün siyasal arenada önemli olduğu ifade edilmişti. Bu konuda özellikle medeniyetler arasında bir tanımlama aracı işlevi de gördügü aşikardır. Bu konuda Huntington'un negatif tez olarak da tasvir edilen medeniyetler çatışması tezi devreye girmektedir. Şöyle ki:

Hipotezime göre, bu yeni dünyada çatışmanın temel kaynağı, öncelikli olarak ideolojik ya da ekonomik olmayacaktır. İnsanlar arasındaki büyük bölünmelerin ve çatışmanın başlıca kaynağı kültürel olacaktır. Ulus-devletler dünya meselelerinde en etkili aktörler olmaya devam edecek; ancak, küresel politikada en önemli çatışmalar farklı uygarlıklardan olan uluslar ve gruplar arasında çıkacaktır. Uygarlıkların çatışması küresel politikaya egemen olacaktır. Uygarlıklar arasındaki fay hatları geleceğin savaş hatları olacaktır (Huntington, 2001, s.16)

Şüphesiz bu iddia terörizmi gerekçelendirmez. Ancak şurası açıktır ki medeniyetler arasında modernite ve onun dinamiğini oluşturan küresel teknolojik imkanlara ulaşım değişkendir. Bu nedenle aslında bu tez terörizmin gelecekte (ki geldi) nereden kaynaklanabileceği iddiasını örtük olarak taşır. Said (2007) bu iddiayı 'Cehaletin Çatışması' olarak tanımlamış ve Huntington'un düşünceleri İslam'a dönük saldırganca bir tutum olarak tanımlamıştır. Dolayısıyla Huntington'un tezine göre İslam medeniyeti doğal olarak terörizmin kaynağı olarak tanımlanmıştır. Nitekim 2001 DTM olayı da, bu tanımlamanın eyleme dökülmüş hali olarak tüm dünyaya ilan edilmesidir. Ya da tüm dünyanın böyle bir tanıma ikna edilmesi için 2001 DTM eylemin icrasına girişilmiştir.

Huntington (2001, s.216) terörizmin özellikle İslam ile Batı arasında yaşanacağını ancak bir savaşın çıkma olasılığının olmadığını ifade eder. Nitekim Said (2007:111), Huntington'un bu tezi neticesinde birçok Batı devlet adamının İslam hakkında ahkam kesmeye giriştiğini de vurgular. Ancak yine de Huntington'un bu tezi, İslam ile terörizm arasında eşitsizlikler üzerinden bir bağ kurmanın ifadesidir. Bu bağlamda Huntington, kışkırtıcı bir tavırla, Batı devletlerini korumacilığa ve nispeten yeniden totaliterizmin yeşermesinin tohumlarını ekmeye çağırır: 
“Terörizm, hoşgörüsüzlüğün canice ortaya çıkışıdır. Hoşgörüsüzlüğe verilen taviz, insanlık için her zaman çok kötü olmuştur. Hoşgörüsüzlüğün canice tezahürüne hızla, sebatla ve kararlılıkla karşılık vermek gerekir. Ama etkili ve güvenilir olmak için tutarlılık şarttır. Başka bir deyişle, nerede karşılaşırsak karşılaşalım, hoşgörüsüzlükle kararlılık ve cesaretle mücadele edilmelidir. Eğer tutarlı davrandığımızı gösterebilirsek, bu çabaya katılacakların sayısı artar, karşı çıkanlar azalır. Sivil toplumun bireyin bağımsızlığını ve haklarını korumak için -ne kadar farklı olursa olsun- ayaklandığı bir zamanda ne terörist eylemlere tepki göstermekte ihmalkâr davranabiliriz ne de başka eylemlere izin verebiliriz. Terörizme ve hoşgörüsüzlüğün her biçimine hızla ve kararlılıkla tepki göstermeyi başaramazsak bu bize çok pahalıya mal olacak, savaşa bile yol açabilecektir" ( Huntington, 2001, s.269)

Görüldüğü gibi hedef tahtasına oturttuğu İslam'a dönük Batılı devletlerin şiddet politikalarına sarılmaları çağrısını yapmaktan da geri durmaz. Nitekim 2001 DTM olayı ile de birçok devletin güvenlik politikalarını daha fazla benimsediği de görülmüştür.

Huntington terörizmin oluşması sürecinin nedenlerine ek olarak organize olma sürecini de ifade etmiştir. Bunu da kurumlaşma ile ifade etmiştir:

"Kurumlaşma, örgütlerle usûllerin itibar ve istikrar kazanmaları sürecidir... Aynı şekilde, belli bir örgüt veya usulün kurumlaşma düzeyi de, onun uyarlanabirliği (adaptability), karmaşıklığı, özerkliği ve tutarlığı ile ölçülebilir. Bu kriterleri belirtip ölçebilirsek, siyasal sistemleri kurumlaşma düzeyleri açısından mukayese edebiliriz. Üstelik, bir siyasal sistemdeki belli örgüt ve usûllerin kurumlaşma derecelerindeki artış ve azalışları da ölçme imkânı ortaya çıkar" (Huntington, 1965, s.65).

Bu süreçler bir terör örgütünün oluşum sürecini de ifade etmektedir. Bu analiz El-Kaide gibi uluslararası terör örgütlerinin tarihsel evrimine de işaret etmektedir. Dolayısıyla Huntington, terörizmi hoşgörünün ortadan kalkmasına bağlıyor olsa da aslında terörizmin kurumsal bir faaliyet olduğunu da düşünür. Ancak bu tartışmayı adı geçen kitabında sürdürmez.

\section{Terörizm ve Küreselleşme: Giddens'ın Yorumu}

Terör kavramı yeni dönemin -soğuk savaş sonrası- mitolojik kavramıdır. Belirsizlik kadar belirsiz bir kavramdır. Kavramın içeriğini sabitlemek zordur. Kavramın içeriğindeki istikrarsızlık da anlamlıdır. Ve bu durum kavramın 
üzerindeki bütün uzlaşmalara da gölge düşürür. Bu durumda terör kavramının kendisi son derece operasyonel ve işlevsel kullanıma açık bir kavramdır. Terör kavramı konusunda, her türlü düşünme, önce bütün açıklığıyla şiddet üreten her türlü siyasal, felsefi ve teolojik yaklaşımları dışarıda bırakmak gerekir. Şiddeti her şekilde toplumsal ve politik bir araç olmaktan çıkması esas alınmalıdır. Bireysel ve toplumsal yaşamı aksatacak her türlü şiddete dayalı girişimin olumsuzlanması kamusal alanın bireyler için güvenli bir alan olmasını sağlayacaktır. Bu durum insanlığın bu umutsuz günlerinde bir umut girişimi olarak öncelenmelidir. Kamusal düzeyde bunun gerçekleşmesi insanlı̆̆ın bu zor günlerinde politik istikrar ve güvenin tarihin damarlarında yeniden dolaşmasını sağlayacaktır.

Modernitenin doğuşunu Giddens dört temel öğe ile açıklar: "Yoğun gözetleme, kapitalist girişim, endüstriyel üretim ve şiddet araçlarının merkezi denetiminin pekiştirilmesi" (Giddens,2008, s.13). Bu dört unsur dünyanın çoğunluğunun modernleştiği kabul edilir- çoğunun yeniden örgütlenmesini gerektirmiştir. Bu minvalde devletlerin sinfflara bölünmüş toplumlardan s1nıflı toplumlara geçiş olarak görmektedir. Sınıflara bölünmüş toplumlarda devlet çoğunlukla insanların gündelik hayatları üzerinde askerlik dışında bir baskısının bulunmadığını ayrıca belirtir. Bu toplumların siyasal karakterinin parçalı ve idari menzilinin oldukça düşük olduğunu belirtir (Giddens,2008, s.11). Hatta ona göre böyle toplumlarda devletler modern anlamıyla 'yönetmezler' (Giddens, 2008, s.11). Ancak Giddens bu toplumların da belirli bir iktidar kabı olduğunu ancak modern olmadığını özellikle vurgular. Ancak bu çalışma açısından bu toplumlarda gözetleme ya da izleme diyebileceğimiz unsurun olmayışı terörizmin izini sürmek açısından önemlidir. Çünkü yerel güç kaplarının üzerinde merkezi siyasal aygıtın gücünü kısmi oluşu yerel aktörlerin ya da yasa koyucuların işin kolaylaştırdığı ve kendi istek ve arzularını yerel çapta uygulamaları için çeşitli fırsatlar yakaladıkları anlamına gelir. Nitekim Osmanlı Dönemi'nde yapılan birçok isyanın merkezi otorite yerine yerel otoritelere/beylere olması da bunun başka bir göstergesidir. Bu nedenle sınıflara bölünmüş toplumlar için terörizmin anlamı bugünkü bildiğimiz anlamlar ile bağları söz konusu edilemez. Dolayısıyla terörizm moderniteye verilen bir cevaptır. Nitekim Giddens terörizmin bu gerekçe alanını fundamentalizmde temellendirir. "Geçmişte insanları birbirine düşüren fundamental çatışmaların yavaş yavaş azalışı veya ortadan kalkışını hedefleyen sosyal dü- 
şüncedeki bu tür bir süreğen eğilim karşısında, biz, sosyal hayattaki çatışmaların yaygınlığı konusu üzerinde ısrarla durmak zorundayız. Zira, 'Çatışma', insanlığın tedavisi mümkün olmayan bir hastalığı ve üretkenliğin olduğu kadar yıkıcılığın da kaçınılmaz bir kaynağıdır (Giddens, 1999, s.365). Dolay1sıyla Giddens için çatışma bir unsur olarak varlığını devam ettirecektir. Ancak bu çatışma Huntington'un ön gördüğü gibi medeniyetler arasında olması imkansızdır. Nitekim bu çatışmanın Giddens'ın tabiriyle sınıflı toplum ya da sınıflara bölünmüş toplumlar arasında bile değildir. Sadece küreselleşmeye direnen marjinal unsurlar olarak yorumlanır. Bu bağlamda Giddens'in yaklaşımı itibariyle Huntington oldukça oryantalist arzuların peşinde koşan biri olarak tasvir edilebilir. Çünkü Giddens'ın medeniyet teorilerinin aşırı genelleştirici ve tersi olarak indirgemeci bir tutuma sahip olduğunu düşünür.

“Valery'nin iyi bilinen, Avrupa'nın "yalnızca Asya'nın bir yarımadası olduğu" gözlemi kendi hakkıyla bir medeniyet olmaktan çok büyük dünya kültürlerinin çevresinde kaldığı görülen Avrupa feodal devletlerine uygulandığında bir miktar doğruluğa sahiptir. Barraclough'un etkin bir biçimde belirttiği gibi, ortaçağ Avrupa medeniyetinin birliği "Latin dili, klasik miras ve Hıristiyan dininin bileşimi olduğu" hayali bir şeydir. Asya ve Afrika'nın önemli bölümlerini alan ama Britanya Adalarının, İskandinavya ve Almanya'nın tümünü içermeyen Roma İmparatorluğunun merkezi Akdeniz'deydi. Ortaçağ Latincesi kıtanın yalnızca belli bölgelerinde kurulu ve kalıcı bir kültürel unsurdu ve ne Papalık ne de Kutsal Roma İmparatorluğunun cazibesi gerçekten evrenseldi. Daha sonra "Avrupa" olan şeyin kenarında yerleşmiş olan Bizans İmparatorluğu birleşik gücün ana merkeziydi" (Giddens, 2008, s.121).

Dolayısıyla tek bir medeniyet ya da medeniyetin tekçi yorumu ideolojik hatalar yapmaya yol açar. Giddens böyle bir tuzağın farkında olarak medeniyet tasavvurlarından ziyade geleneksel ve modern ayrımlarını benimsediği açıktır. Eğer bir değişim ya da çatışma olacaksa bu kavramsallaştırma Giddens için küreselleşmedir.

Giddens'a (2011, s.11)göre modernitenin temel niteliklerinden biri “iki 'karşıt' faktör yayılmacılık ve niyetlilik, yani küreselleştirici etkiler ile kişisel ihtiyaç eğilimleri arasında giderek artan karşılıklı bağlantıdır". Bu bağlamda modernitenin tarihi de yenidir. Giddens aracılığıyla dünya çapında -Güloğlu (2018) adlandırmasıyla, 'kurucu korku' olarak rol oynabilecek bir araç olarak- 
terörizm okuması geliştirilecek ise tam da bu iki faktörün yeniden yorumlanmasını gerekli kılmaktadır. Çünkü modernitenin yayılmacılığı karşısında her türlü geleneksel denilebilecek ne varsa çözme ya da ortadan kaldırma eğilimi taşıdığı açıktır. Bu bağlamda çatışma ve direniş doğal bir tepki olarak ortaya çıkması beklenebilir. Ancak niyetlilik kavramsallaştırması yani kişilerin yaşamdan beklentilerinin neler olduğu oldukça değişken ve hatta neo-klasik iktisat açısından 'ihtiyaç üretilir' düşüncesi de hatırlandığında bu uzlaşı oldukça siyasal bir beceri istediği açıktır. Nitekim kendisinin üçüncü yol olarak önerdiği radikal demokrasi tam olarak bu gerilimi aşmaya dönüktür. Böylece aslında terörizme direnmenin araçların üretmektedir. "Modernitenin radikalleşmesi bir başka deyişle küresel bir hale gelmesi artık modernitenin sorunlarının sadece Batıyı değil, aynı zamanda dünyanın öbür coğrafi bölgelerindeki insanları da yakından ilgilendirdiğini ortaya koymaktadır. Bunun en canlı örneği olarak finans sektöründe görülen etkilenmelerin yanı sıra toplumsal olaylarda da hissedilmektedir" (Giddens,2000, s.7). Bu yayılma Giddens için hem sağ hem de sol tarafından ciddi direnç ile karşılaşmıştır (Giddens,2000, s.13).

Küreselleşme kuramı terörizmi anlamak açısından iki yönlü bir etkide bulunur. Birincisi radikal modernitenin yayılmacilı̆̆ 1 anlamında mekanın biçimlendirilmesi ve ihtiyaçların tedarik süreci anlamında niyetlerin belirlenmesi anlamında. Çünkü ona göre "küreselleşme, sadece ya da öncelikle ülkelerin ekonomik açıdan karşılıklı bağımlılıkları anlamına gelmemekte, fakat içinde yaşadığımız dönemde zamanın ve mekanın dönüşümüyle ilgili bir kavramdır" (Giddens, 2000, s.42). Zaman ve mekanın genişlemesi/açılması modern dünyanın temel dinamikleridir. Yapılaşma teorisi için önem arz eden bu kavramsallaştırma yeni kimliklerin üretimi açısından büyük bir rol oynar. Bu bağlamda terörist kimliğinin oluşumu da zaman-mekan uzaklaşması/yakınlaşması diferansiyeli çerçevesinde anlam kazanır. Bu bağlamda bir kez daha aslında yerinden edilen İslam bu defa terörizm yaftası ile yeniden yerleştirilir. Radikal modernitenin anlamlandırma araçları bakımından böyle bir süreç işlemektedir. Dolayısıyla bir medeniyet çatışması teorisinden ziyaden sürekli yeniden anlamlandırılan bir ilişki biçiminden hatta monologdan bahsedilebilir. Tam da bu anlamda devreye öteki kavramsallaştırması girmektedir.

Bugün "medeniyetler çatışması" görüşü öteki kavramını konumlandırmaya dönüktür. Medeniyetler çatışması ötekiyi, radikalleştirerek dıştalayan 
ve antagonistik bir unsur olarak düşünür (Huntington, 2005). Ben ya da biz ve öteki ayrımı mutlaklaştırılır. Öteki mutlak bir tehdit olarak ikame edilir. Uzlaşmazlık yapılaştıılır. Kültürler derin bir iletişimsizliğe dayalı olarak düşman penceresinden düşünülür. Terör bu çerçevede düşman ötekinin silahıdır. Medeniyetler çatışmasının ötekiyi anlamayı ve ufukların kaynaşmasını esas alan özgürleştirici bir umuda rehberlik etmediği pratik olarak da görülmüştür.

Uygarlıkların, toplumların ve bireylerin arasındaki tarihsel bir anlamayı, iletişimi devamlı erteleyen tarihsel bloklar vardır. Bu tarihsel bloklar bütün değişimlere rağmen israrla güncelliklerini yitirmezler ve yeniden kendilerini üretirler. Bunlar kültürlerarası iletişimi sabote eden tarihsel önyargı bagajlarıdır. Bunlar "ufukların kaynaşması"nı engellerler. Dünya tarihi kültürlerin birbirini anlamasını beklemektedir. Dünya tarihinde sahici bir dönüşüm ya da "ebedi barış" ancak böyle olanaklılık kazanabilir. Burada üzerinde durulması gereken en önemli kavram öteki kavramıdır. Öteki kavramı siyasal ve teorik düzeyde bu tartışmayı yönlendirecek en önemli kavramdır. İslami terör kavramı nihayetinde ötekiye ilişkin bir kavramdır. Hem antropoloji hem de siyasal düşünceler tarihi açısından öteki kavramına baktığımızda, öteki, 'ben' kavramının kuruluşunu sağlayan temel bir unsurdur. Ben kendi dışındaki dünyayı sabitlemek ve olumsuzlamak girişimiyle "radikal ötekiye" gereksinim duyar. Öteki olmaksızın ben'in inşası güçtür. Onun için ötekinin bazen fantastik olarak da üretilmesi gerekir (Zizek, 2004). Soğuk savaş sonrası dönemin bu anlamda yeni savaş stratejisinin en önemli aracı ya da ötekisi olarak İslami terör kavramının istihdam edildiği söylenebilir. Batı uygarlığı etnosentrik bir biçimde kendini merkeze alarak diğer uygarlıklara karşı son derece saldırgan ve yokedici bir tutumu öne çıkarmıştır. Bu çerçevede daima kendisinin karşısına bir öteki çıkararak tarihsel olarak varlığını sürdürmüştür. Soğuk savaş yıllarında komünizm bu işlevi görmesine rağmen aslında bir tür batının ebedi ötekisi doğu dünyası ve özelde İslam Uygarlı̆̆ı olmuştur. Oryantalizm tartı̧maları bu arka plandaki sürekliliği fazlasıyla ortaya koymuştur. Soğuk savaşın bitiminde İslam ve terör kavramlarının birarada kullanılması bu süreklilik içinde ele alınmalıdır. Yaşadığımız konjonktürde nasıl ortaya çktığına ilişkin bütün belirsizliklere rağmen El Kaide, İşiD ya da Boko Haram gibi İslam ve terör kavramların bir araya getiren bu pratiklerin yine bu oryantalistik tahayyülü çok kolayca beslediği söylenebilir. 
Düşünme biçimleri bazen adeta 'bir ebedi algr' ile maluldürler. Bu durum sosyal teoride ötekinin hem teorik hem pratik düzeyde nasıl üretildiğine ilişkin olarak da bir karşılık bulmuştur. Bunun tipik örneklerinden birisi 'oryantalizm' olmuştur (Said,1999). Yukarıda değinmeye çalıştığımız öteki kavramının batı dışı toplumlara ilişkin olarak derin arka planını oluşturan çerçevedir. Oryantalizm doğuya ilişkin olarak yapılan kültürel araştırmaların batının lehine doğunun aleyhine olacak şekilde yürütülmesidir. Oryantalizmin imgeleminde bir taraf bütün iyi sıfatları yüklenirken diğeri bütün olumsuzlukların alanı olarak karşılık bulur. Batı iyinin alanıdır. Batının ötekisi doğudur. İslami terör kavramı bu anlamda oryantalist batı imgeleminin güncellenmesidir. Bu yönüyle İslami terör kavramı bir oryantalizm olarak görülebilir.

İslam bir din ve kültür olarak değerlendirildiğinde hiçbir zaman tek bir evrensel yoruma indirgenemez. Sosyal gelişmeler yine sosyalin faktörleriyle açıklanmalıdır.Bu kavram dinin algılanmasını da bozan bir indirgemeciliktir. İnsanlık durumu tarihe bakılarak anlaşılmalıdır. Dinin kendisi tarihsel olarak gerçekleşen olaylarla özdeşleştirilemez. Tarihsel eylem ekonomik ve siyasal durumla ilişkilendirilerek açıklanmalıdır (Lewins,2011). İslami terör kavramına ilişkin analizlerde küresel hegemonyanın bir değişken olarak etkisine bakılmadan yapıldığı rahatlıkla görülebilir. Tarihsel yapıları göz önünde bulundurmadan bir metodolojik indirgemecilik aracılığıyla bu kavramsal mekanizmalar üretilebilmektedir. Bu kavramsallaştırma da doğu-batı, kuzeygüney, ekonomik ve siyasal eşitsizlikler ve tahakküm stratejilerinin unutulduğu rahatlıkla söylenebilir. Kavramlar dünyayı görmemize imkân verdikleri gibi görmemizi de engellerler. Kavramlar körleştirir de. Terör kavramı İslam toplumlarının küresel eşitsizliklerle olan bağını ve siyasal tahakküme duyarlı yapılarını görmemizi engelleyen bir kavram olarak da işlevselleştirilmiştir. İnsanlık durumunun ebedi bir onaylanmasına kaynaklık eder ve özgürlük, adalet ve eşitlik açısından inşa edilecek bir dünya olasılığını da erteler. İletişimi bozar. İslam'ın dünya barışına katkısını da erteleyen bir kavramdır. Bu terör söylemi İslam'ın tarihsel birikimini ve entelektüel derinliğini hor gören bir yaklaşımı önceliyor. Tarih; herkesi ötekiyi radikal bir düşünmeye davet olarak anlaşılmalıdır. Küreselleşmenin önkoşulu bu olmalıdır. Demokrasinin tesisi ancak ötekiyi anlamak ile mümkündür. Demokrasi teorisi farklılıklara dayalı bir siyasettir. Farklılıkları reddeden kavramlar siyasal yaşam 
için bir tehdittir ve kamusal yaşamdaki her türlü iletişimi sürekli bozarak üretilirler. Bu bağlamda kavramlar yeniden düşünülmelidir. Kültürlerarası iletişimi sağlayacak sahih bir dil inşa edilmelidir.

\section{Sonuç ve Değerlendirme}

Politik tartışmaların bir hegemonya ve güç mücadelesini meşrulaştırma işlevi gördüğü söylenebilir. Politik tartışmalara ek olarak düşünce üretimi de bu tartışmanın temel zemini olarak işlev görür. Bu tartısma sürecinde de kavramların konumlandırılma biçimi direkt olarak bu güç mücadelelerinin temel yönelimlerine uygun olarak bir karşılık bulur. Terör kavramı diğer birçok kavram gibi bu zeminde mevzilendirilmiştir. Bilhassa bu kavramın İslam ile birlikte kullanılması tartışamaya kültürel ve medeniyet zemininde bir perspektif kazandırarak terör olgusu yapısal düzeyde bir karşılaşmanın alanı olarak görülmüştür. Kültür politik düzeyde ötekinin üretimi için olumsuz bir imge olarak görülmeye başlanmıştır. İslam'ın kriminal bir olgu ve kaynak olarak görülmesi terör kavramının kullanımı bağlamında karşılık bulmuştur. Oryantalist metodolojinin sunduğu tarihsel okuma bu durumun üretilmesine imkan sağlamıştır. Zaten oryantalist okuma İslam'ın batı bilincinde negatif bir imge olarak zaten konumlandırmıştır. Politik güncelliğin güç arayışı bağlamında bu teorik arkapılan tereddütsüz bir biçimde mevzi almıştır. Medeniyetler çatışması ve terör kavramını geç modernitenin düzleminde ele almak bu yönüyle kültürel ve politik durumu anlamayı kolaylaştıracaktır. Batı düşünce dünyasından iki farklı düşünürün bir kavramı ve tarihsel dünyayı yorumlamada ortaya koydukları düşünsel farklılık günümüzdeki yönelimleri anlamada işlevsel olacaktır. Medeniyetler çatışması ya da moderliğin sonuçları değerlendirmeleri doğu batı ilişkilerini de yorumlamaya imkan vermektedir.

Huntington'a göre (2001) medeniyet kendiliğinden çatışmayı üreten bir dinamik olarak görülür. Bu yaklaşım büyük ölçüde Batı kültür kodlarının d1şında kalan havzalarda çatışmacı ve yıkıcı potansiyellerin olduğu yaklaşımı öne çıkmaktadır. Burada İslam külttür havzası ile batı uygarlığı büyük ölçüde yeni çatışma alanı olarak görülmektedir. Çatışmanın kültürün içsel dinamiklerinden kaynaklandığı görüşünün ağırlık kazandığı söylenebilir. Yani çatışma kültürün ürettiği bir durumdur. Bu yönüyle bazı kültür ya da medeniyetler idiğerleri için birer tehdit olarak değerlendirilirler. Bu yaklaşım özcü 
ve indirgemeci bir metodoloji çerçevesinde bir anlama sahiptir. Giddens'a göre (2000) bu yaklaşım tarihsel bir gelişme olarak küreselleşmenin toplumlar ve kültürler için ürettiği tehditleri görmemiz gerektiğini ifade eder. Toplumlar kültürel olarak çatışmacı ve yıkıcı potansiyellere sahip değildirler. Aslında küreselleşme ya da sınıfsal dinamikler ve eşitsizlik gibi değişkenlerin bireylerin ve toplumların politik yönelimlerini etkilediğini belirterek şiddet durumunun bu reel olgular üzerinden ele alınması gerektiği düşüncesini ileri sürer. Çatışma bütün tarihsel durumlarda karşılaşabileceğimiz bir toplumsal olgudur. Fakat bunun bir şiddet durumuna dönüşmesi beklenti ve taleplerin yönetimi ile bağlantılı bir sonuç olarak ortaya koyar. Bu iki farklı yaklaşımda esas olan Huntington çatışmayı bir şiddet durumu olarak görüp kurumsallaştırma yönünde işlevselleştirici bir yaklaşıma dönüştürürken, Giddens bunu toplumun beklentilerinin yönetilmesi açısından işlevsel olarak görmüştür. Önyargıları yapılaştıran kavramlar nükleer silahlardan daha tehlikelidir. Dünya barışı için en önemli adım gerçeğe dayalı bir dilin imkânları içerisinde bir siyaset, bir kamusal yaşam ve iletişimi tasarlamak olacaktır. 


\section{EXTENDED ABSTRACT}

\section{Institutionalization of Terrorism as a Political Instrument: Huntington and Giddens

\author{
Mehmet Özcan \\ Ankara Hacı Bayram Veli University
}

It can be said that political debates function to legitimize a struggle for hegemony and power. In addition to political debates, thought generation also serves as the basis for this debate. In this discussion process, the way the concepts are positioned finds a response directly by the basic directions of these power struggles. The concept of terrorism is positioned on this ground like many other concepts. In particular, the use of this concept in conjunction with Islam has given the discussion a cultural and civilization perspective, and the phenomenon of terrorism has been seen as a field of encounter at a structural level. Culture has started to be seen as a negative image for the production of the other at the political level. The fact that Islam is seen as a criminal phenomenon and source has found a response in the context of the use of the concept of terrorism. The historical reading offered by the orientalist methodology has enabled this situation to be produced. The orientalist reading has already positioned as a negative image in the western consciousness of Islam. This theoretical background has taken place without hesitation in the context of the pursuit of power of the political current. Addressing the concept of clash of civilizations and terrorism at the level of late modernity will make it easier to understand the cultural and political situation. A concept of two different thinkers from the Western world of thought and the intellectual difference they present in interpreting the historical world will be functional in understanding current trends.

The clash of civilizations or evaluating the results of modernity also allows the interpretation of east-west relations. The functionalism of Durkheim (2012) in the sociology literature; According to Giddens (2011, p.103) beyond the Atlantic, functionalism resurfaced with Malinowski, and the development of structural-functionalism, along with Parsons, which marked the 1960s, could exert 'pressure' concerning Durkheim, in which institutions or institutions were external. It can be said to be seen as an organism. Together 
with Parsons, the organism approach has been replaced by 'wheels', that is, system conceptualization. However, as a result of Weber 's claim that the action may have' unintended consequences', the interpretative approach - it finds its strong echo in phenomenological methods - has developed. In these approaches, it was suggested that the social world, that is, institutions, was formed by practical performances and that the actor was the perpetrator of this formation process. Although it is accepted that these debates constitute a wide collection, this study specifically refers to the phenomenon of 'institutionalization' discussed by Berger and Luckman (2008). According to them, institutionalization $(2008$, p.80) is subject to "habitualization". Each frequently repeated action begins to pour into a mold, which can be reproduced with an effort-saving effort and is grasped by its performers as an ipso facto model. Mutatization also implies that the action in question may be repeated in the future in the same manner and with the same saving effort". Therefore, the stereotyping of repetitive and repetitive actions constitutes the basic dynamics of institutionalization.

It can be said that the institutionalization process of terrorism has different degrees in each society. However, with all this, it can be said clearly that terrorism has a tendency towards institutionalization in late modernity and that it has even been institutionalized. Because now we can talk about a history of terrorism. Indeed, the completion of the institutionalization process is possible with the formation of the historicity of terrorist acts. In other words, it is a fact that terrorism operates as a historical entite and in which we have to learn to live with terrorism in today's world. The institution is "a social structure and mechanism organized by human societies that will meet, manage and manage the needs of people in various degrees" (Adak, 2011, p.29). People can apply different methods to meet their needs. Indeed, terrorism can be considered one of these methods. For example, when looking at many texts where the causes of terrorism are discussed, the following causes are encountered: Misery, frustration, trouble, grief and despair, economic and social inequality, resource scarcity, legal problems, political factors, resistance to colony, ideology, psychological problems, political pressure and violence (TBB , 2006). In general, it can be said that terrorism aims to destroy the "old order". Of course, such an effort or this purpose can never be considered legitimate. 
According to Giddens (2011, p.11), one of the basic qualities of modernity is "two" opposing "factors are the increasingly mutual connection between expansionism and intent, that is, globalizing effects and personal need trends". In this context, the history of modernity is new. Globalization theory has a two-way effect in terms of understanding terrorism. The first is to shape the space in the sense of the diffusion of radical modernity and to determine intentions in terms of the supply process of needs. Because, according to him, "globalization does not only mean economic interdependencies of countries, but it is a concept related to the transformation of time and space in the period we live in" (Giddens, 2000, p.42). Huntington (2001, p.216) states that terrorism will occur especially between Islam and the West, but there is no possibility of a war. Said (2007, p.111) emphasizes that as a result of this thesis of Huntington, many Western statesmen have attempted to cut down on Islam. However, this thesis of Huntington is an expression of establishing a link between inequality between Islam and terrorism.

According to Huntington (2001), civilization is seen as a dynamic that automatically generates conflict. This approach stands out with its conflicting and destructive potentials in basins that are largely outside the Western cultural codes. Here, the Islamic cultural basin and western civilization are largely seen as a new area of conflict. It can be said that the view that the conflict stems from the internal dynamics of the culture gains weight. In other words, conflict is a situation produced by culture. In this respect, some cultures or civilizations are considered as a threat to others. This approach has a meaning within the framework of an essentialist and reductionist methodology. According to Giddens (2000), this approach states that as a historical development, we should see the threats that globalization poses for societies and cultures. Societies do not have culturally conflicting and destructive potentials. In fact, he argues that variables such as globalization or class dynamics and inequality affect the political orientation of individuals and societies, suggesting that the state of violence should be addressed through these real facts. Conflict is a social phenomenon that we can encounter in all historical situations. However, it turns out to be a violent situation as a result related to the management of expectations and demands. While Huntington sees conflict as a violent situation and transforms it into a functionalizing approach to ins- 
titutionalization, which is essential in these two different approaches, Giddens sees this functionally in terms of managing the expectations of society. Concepts that construct prejudices are more dangerous than nuclear weapons. The most important step for world peace will be to design a politics, a public life, and communication within the possibilities of a language based on reality.

\section{Kaynakça / References}

Adak, N. (2011). İstanbul toplumunun temel yapı taşı: Aile .(Ed. S. Güçlü). Sosyolojik Kurumlara Bakış, İstanbul: Kitabevi Yayınları.

Berger,P. ve Luckmann,T.(2008).Gerçekliğin sosyal inşast: bir bilgi sosyolojisi incelemesi. (Çev. V. S. Öğütle), İstanbul:Paradigma Yayınları.

Durkheim,E.(2012).Sosyolojik yöntemin kuralları. (Çev.C. B. Akal).Ankara:Dost Kitabevi.

Foucault,M. (2003).Ders özetleri. (Çev. T. Ilgaz).İstanbul:YKY

Foucault, M. (1992).Hapishanenin doğuşu, (Çev. M. A. Kılıçbay). Ankara:İmge

Giddens, A. (2008). Ulus devlet ve şiddet,(Çev. C. Atay), İstanbul: Kalkedon Yayınları.

Giddens, A.(2000). Üçüncü yol. (Çev. M. Özay), İstanbul:Birey Yayınları.

Giddens, A.(2010).Modernite ve bireysel kimlik. (Çev.Ü. Tatlıcan), İstanbul:Say Yayınları.

Giddens, A. (1999).ileri toplumlarm sinı yapısı.(Çev. Ö. Baldık).İstanbul:Birey Yayınlari.

Gidden, A. (2011). Sosyolojinin savunusu. (Çev.İ. Kaya). İstanbul:Say Yayınları.

Güloglu, M.F.(2018).Baba otoritesinin yeniden üretimi. Akdeniz İnsani İlimler Dergisi, $8(1), 165-186$.

Habermas, J. (2001).iletişimsel eylem teorisi, (Çev.M. Tüzel).Ankara:Kabalcı Yayınları. Huntington, S.(2001). Medeniyetler çatışması (Çev. M. Yılmaz).Ankara:Vadi Yayınları. Huntington, S.(2005). Asker ve devlet (Çev. U. Kızılaslan).İstanbul: Salyangoz Yayınları.

Huntington, S. (1965).Siyasal düzen ve siyasal bozulma.(Çev. E. Özbudun),Ankara Üniversitesi Hukuk Fakültesi Dergisi, 22-23(1-4), 55-107.

Lewins, F.(2011). Sosyal bilimlerin metodolojisi.(Çev.A.V. Taştan ). Ankara:Lotus.. Laquer, W. (2002). A history of terrorism. New York: Transaction Publishier.

Said, E. W.(1999). Şarkiyatç̧lı. (Çev. Berna Ünler), İstanbul:Metis.

Said, E. W. (2007). Cehaletin Çatışması. (Çev: G. Gökalp), Doğu Batı Dergisi, 10(41), 109-117.

Türkiye Barolar Birliği. (2006).Türkiye ve terörizm. Rapor Metni no:107. Ankara:TBB Yayınları. 
Weber, M. (2004).Sosyoloji yazıları. (Çev.T. Parla).İstanbul: ந̇etişim Yayınları. Zizek,S.(2002) Kirılgan temas. (Çev. T. Birkan). İstanbul:Metis.

\section{Kaynakça Bilgisi / Citation Information}

Özcan, M. (2020). Politik bir araç olarak terörizmin kurumsallaşması: Huntington ve Giddens. OPUS-Uluslararası Toplum Araştırmaları Dergisi, 15(10. Yil Özel Say1s1), 5474-5495. DOI: 10.26466/opus.738465 